\title{
The National Flood-Frequency Program-Methods for Estimating Flood Magnitude and Frequency for Natural Basins in Texas, 2001
}

\section{Introduction}

Estimates of the magnitude and frequency of flood-peak discharges and flood hydrographs are used for a variety of purposes, such as for the design of bridges, culverts, and flood-control structures; and for the management and regulation of flood plains. To provide simple methods of estimating flood-peak discharges, the U.S. Geological Survey (USGS) has developed and published regression equations for every State, the Commonwealth of Puerto Rico, American Samoa, and a number of metropolitan areas in the United States. In 1993, the USGS, in cooperation with the Federal Emergency Management Agency and the Federal Highway Administration, compiled all current USGS statewide and metropolitan area regression equations into a computer program, titled "The National Flood-Frequency (NFF) Program” (Jennings and others, 1994).

Since 1993, new or updated regression equations have been developed by the USGS for various areas of the Nation. These new equations have been incorporated into an updated version of the NFF Program.

This Fact Sheet describes the application of the updated NFF Program to streams that drain natural (rural and unregulated) basins in Texas. Information on obtaining the NFF software and Fact Sheets for other areas of the Nation is provided at the end of this Fact Sheet.

\section{Overview}

Asquith and Slade (1997) developed regional regression equations to estimate peak discharges $\left(\mathrm{Q}_{\mathrm{T}}\right)$ in natural basins in Texas, with recurrence intervals $(\mathrm{T})$ ranging from 2 to 100 years. These equations are included in the NFF Program. Asquith and Slade (1997) defined a natural basin as a basin with less than 10 percent impervious cover, less than 10 percent of its drainage area controlled by reservoirs, and no other human-related factors affecting streamflow. Separate sets of equations were developed for each of 11 hydrologic regions in Texas (fig. 1), which were determined on the basis of physiography and climatic conditions. For 5 of the 11 regions, the relation between peak discharge frequency and contributing drainage area was non-linear, requiring that one set of equations be developed for drainage areas less than 32 square miles and another set be developed for drainage areas greater than 32 square miles, giving rise to 16 sets of equations for the state (table 1).

The regression equations were developed from peak-discharge records through 1993 at 527 streamgaging stations with natural streamflow conditions in Texas. Asquith and Slade (1997) summarized streamgaging-station information, peakdischarge records, and peak-discharge estimates for 559 gaging stations in Texas, and 105 streamgaging stations in Arkansas, Louisiana, New Mexico, and Oklahoma.

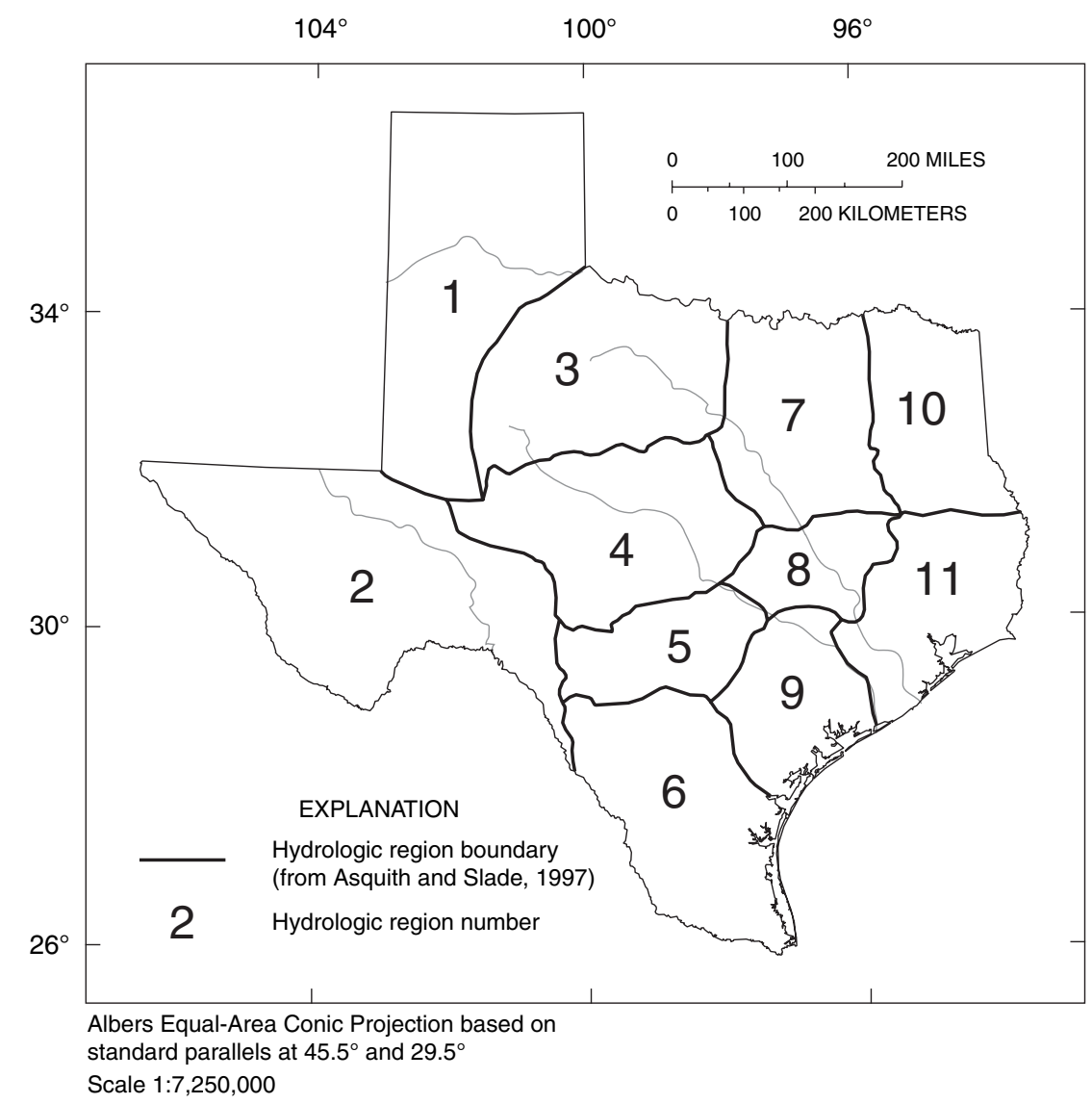

Figure 1. Hydrologic regions of Texas. 
Additional regression equations have been developed for some distinct areas in Texas, including streams in the vicinity of Highland Lakes, central Texas (Asquith, Slade, and Lanning-Rush, 1996), and tributaries to the Brazos River (Raines, 1998) and the Colorado River (Asquith, 1998). These additional regression equations are not included in the NFF Program. Users interested in documentation for these equations should contact the Texas District Office of the USGS, Austin, TX.

Asquith and Slade (1999) also developed a computer program that uses a sitespecific approach to construct a unique set of regression equations to estimate $\mathrm{Q}_{\mathrm{T}}$ for recurrence intervals ranging from 2-100 years for specific ungaged sites in natural basins in Texas. The computer program uses only streamgaging stations with basin characteristics similar to those for the ungaged site to develop the site-specific equations. A cluster analysis selects the stations from a data base that contains a total of 664 streamgaging stations, 559 in Texas and 105 in Arkansas, Louisiana, New Mexico, and Oklahoma. The program then uses multivariate generalized leastsquares linear regression to develop the equations. Because a new set of equations is developed each time the program is run, no equations for this method are included in this fact sheet and the program is not included in the NFF Program. The report and the software required to run the program is available on the World Wide Web at URL http://water.usgs.gov/pubs/wri/ wri994172. Users interested in the sitespecific approach may also contact the Texas District Office of the USGS, Austin, TX.

\section{Procedure}

The explanatory variables used in the regional regression equations of Asquith and Slade (1997) are expressed in the inchpound system of units; however, the NFF Program will accept and report either the inch-pound or the metric system of units. The explanatory variables used in the equations are:

Contributing drainage area (A), in square miles, is the area of the basin contributing to flow in the stream, determined from USGS topographic maps.

Basin shape factor ( $\mathrm{SH})$, dimensionless, is the ratio of the square of the stream length to the contributing drainage area and represents the ratio of the longest stream length to the mean width of the basin. Stream length, in miles, is the length of the longest mapped channel, from the gaging station to the headwaters and is determined from USGS, 1:100,000-scale topographic maps.

Stream slope (SL), in feet per mile, is the ratio of the change in elevation of the longest mapped channel from the gaging station to the headwaters to the length of the longest mapped channel determined from USGS, 1:100,000-scale topographic maps.

The regional regression equations of Asquith and Slade (1997) and the weighted standard errors of estimate in percent are shown in table 1 . The weighted standard error of estimate is a measure of the goodness of fit between a regression equation and the data used to derive the equation. Errors in the $Q_{T}$ estimates for about two thirds of the stations used in the regression analyses were within the given standard errors. Errors in the $Q_{T}$ estimates for ungaged sites are somewhat larger than the standard errors of estimate shown in table 1 , and errors increase appreciably when any of the basin characteristics used in the equations are near or beyond the range limits shown in table 2. Asquith and Slade (1997) provide procedures to compute the confidence intervals associated with flood estimates computed from the regression equations, as well as procedures that can assess the applicability of an equation to a given set of basin characteristics.

In regions for which the relation between peak discharge and contributing drainage area is non-linear and two sets of equations are presented in table 1 (Regions $3,4,5,7$, and 10 ), a weighting procedure is suggested to combine the estimates from the two sets of equations if the contributing drainage area is between 10 and 100 square miles. The weighted estimate, $Q_{T W}$, is computed as:

$$
Q_{T W}=[2-\log (A)] Q_{T 1}+[\log (A)-1] Q_{T 2},
$$

where

\section{$Q_{T W} \quad$ is the weighted peak discharge associated with T-year recur- rence interval, \\ $Q_{T 1} \quad$ is the peak discharge associ- ated with the equations for sites with contributing drain- age areas less than 32 square miles, \\ $Q_{T 2} \quad$ is the peak discharge associ- ated with the equations for sites with contributing drain- age areas greater than 32 square miles, and}

$\log (A) \quad$ is the common (base 10) logarithm of the contributing drainage area for the ungaged site.

This weighting procedure is not included in the NFF software. Users of the software should obtain the estimates from the two sets of equations provided in NFF and then manually solve the weighted estimate equation.

\section{-Prepared by Stephen S. Sumioka and Kernell G. Ries III}

\section{References}

Asquith, W.H., 1998, Peak-flow frequency for tributaries of the Colorado River downstream of Austin, Texas: U.S. Geological Survey Water-Resources Investigations Report 98-4015, 19 p.

Asquith, W.H., and Slade, Raymond, Jr., 1997, Regional equations for estimation of peak-stream flow frequency for natural basins in Texas: U.S. Geological Survey Water-Resources Investigations Report 96-4307, 68p.

1999, Site-specific estimation of peak-stream flow frequency using generalized least squares regression for natural basins in Texas: U.S. Geological Survey Water-Resources Investigations Report 99-4172, 19 p.

Asquith, W.H., Slade, R.M., Jr., and Lanning-Rush, Jennifer, 1996, Peak-flow frequency and extreme flood potential for streams in the vicinity of the Highland Lakes, central Texas: U.S. Geological Survey Water-Resources Investigations Report 96-4072, 1 sheet. 
Jennings, M.E., Thomas, W.O., Jr., and Riggs, H.C., comp., 1994, Nationwide summary of U.S. Geological Survey regional regression equations for estimating magnitude and frequency of floods for ungaged sites, 1993, U.S. Geological Survey Water-Resources Investigations Report 94-4002, $196 \mathrm{p}$.

Raines, T.H., 1998, Peak-discharge frequency and potential extreme peak discharge for natural streams in the Brazos River Basin, Texas: U.S. Geological Survey Water-Resources Investigations Report 98-4178, 42 p.

For more information contact:

U.S. Geological Survey

Office of Surface Water

415 National Center

Reston, Virginia 20192

(703) 648-5301

USGS hydrologic analysis software is available for electronic retrieval through the World Wide Web (WWW) at http://water.usgs.gov/software/ and through anonymous File Transfer Protocol (FTP) from water.usgs.gov (directory: /pub/software). The WWW page and anonymous FTP directory from which the National Flood-Frequency software and user documentation can be retrieved are http://water.usgs.gov/software/nff.html and

/pub/software/surface_water/nff, respectively.

Additional earth science information is available from the USGS through the WWW at http://www.usgs.gov/ or by calling 1-888-ASK-USGS.

Table 1. Regression equations for estimating peak-streamflow frequency for hydrologic regions of Texas (from Asquith and Slade, 1997)

$\left[\mathrm{Q}_{\mathrm{T}}\right.$, peak discharge, in cubic feet per second for recurrence interval, $\mathrm{T}$, in years; A, contributing drainage area, in square miles; SH, basin shape factor, dimensionless; and SL, stream slope, in feet per mile]

\begin{tabular}{|c|c|c|c|}
\hline Regression equation & $\begin{array}{l}\text { Weighted } \\
\text { standard } \\
\text { error of } \\
\text { estimate, } \\
\text { in percent }\end{array}$ & Regression equation & $\begin{array}{c}\text { Weighted } \\
\text { standard } \\
\text { error or } \\
\text { estimate, } \\
\text { in percent }\end{array}$ \\
\hline
\end{tabular}

\section{$\underline{\text { Region } 1}$}

$\mathrm{Q}_{2}=16.1 \mathrm{~A}^{1.04} \mathrm{SH}^{-0.537}$

$\mathrm{Q}_{5}=53.2 \mathrm{~A}^{0.958} \mathrm{SH}^{-0.444}$

$\mathrm{Q}_{10}=96.0 \mathrm{~A}^{0.921} \mathrm{SH}^{-0.400}$

$\mathrm{Q}_{25}=178 \quad \mathrm{~A}^{0.885} \mathrm{SH}^{-0.356}$

$\mathrm{Q}_{50}=263 \quad \mathrm{~A}^{0.864} \mathrm{SH}^{-0.330}$

$\mathrm{Q}_{100}=371 \quad \mathrm{~A}^{0.847} \mathrm{SH}^{-0.307}$

\section{$\underline{\text { Region } 2}$}

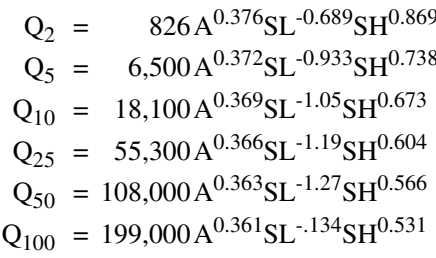

120

92

88

92

99

107

\section{Region 3}

(Sites with contributing drainage areas less than 32 square miles)

$$
\begin{aligned}
\mathrm{Q}_{2} & =119 \mathrm{~A}^{0.592} \\
\mathrm{Q}_{5} & =252 \mathrm{~A}^{0.629} \\
\mathrm{Q}_{10} & =373 \mathrm{~A}^{0.652} \\
\mathrm{Q}_{25} & =566 \mathrm{~A}^{0.679} \\
\mathrm{Q}_{50} & =743 \mathrm{~A}^{0.698} \\
\mathrm{Q}_{100} & =948 \mathrm{~A}^{0.715}
\end{aligned}
$$

20
92
88
92
99
07
75

\section{$\underline{\text { Region } 3}$}

(Sites with contributing drainage areas greater than 32 square miles)

$$
\begin{aligned}
& \mathrm{Q}_{2}=8.05 \mathrm{~A}^{0.668} \mathrm{SL}^{0.659} \mathrm{SH}^{0.189} \\
& \mathrm{Q}_{5}=42.0 \mathrm{~A}^{0.626} \mathrm{SL}^{0.574} \\
& \mathrm{Q}_{10}=91.9 \mathrm{~A}^{0.579} \mathrm{SL}^{0.537} \\
& \mathrm{Q}_{25}=233 \quad \mathrm{~A}^{0.523} \mathrm{SL}^{0.476} \\
& \mathrm{Q}_{50}=448 \quad \mathrm{~A}^{0.484} \mathrm{SL}^{0.425} \\
& \mathrm{Q}_{100}=835 \quad \mathrm{~A}^{0.447} \mathrm{SL}^{0.372}
\end{aligned}
$$

\section{Region 4}

(Sites with contributing drainage areas less than 32 square miles)

$$
\begin{aligned}
\mathrm{Q}_{2} & =97.1 \mathrm{~A}^{0.626} \\
\mathrm{Q}_{5} & =196 \mathrm{~A}^{0.650} \mathrm{SH}^{0.257} \\
\mathrm{Q}_{10} & =293 \mathrm{~A}^{0.697} \mathrm{SH}^{0.281} \\
\mathrm{Q}_{25} & =455 \mathrm{~A}^{0.741} \mathrm{SH}^{0.311} \\
\mathrm{Q}_{50} & =53 \mathrm{~A}^{0.927} \mathrm{SL}^{0.558} \mathrm{SH}^{0.333} \\
\mathrm{Q}_{100} & =51 \mathrm{~A}^{0.968} \mathrm{SL}^{0.627} \mathrm{SH}^{0.353}
\end{aligned}
$$

\section{$\underline{\text { Region } 4}$}

(Sites with contributing drainage areas greater than 32 square miles)

$$
\begin{array}{rlr}
\mathrm{Q}_{2} & =0.0066 \mathrm{~A}^{1.29} \mathrm{SL}^{2.09} & 72 \\
\mathrm{Q}_{5} & =0.0212 \mathrm{~A}^{1.24} \mathrm{SL}^{2.18} & 51 \\
\mathrm{Q}_{10} & =0.0467 \mathrm{~A}^{1.20} \mathrm{SL}^{2.18} & 49 \\
\mathrm{Q}_{25} & =0.102 \mathrm{~A}^{1.16} \mathrm{SL}^{2.18} & 54 \\
\mathrm{Q}_{50} & =0.166 \mathrm{~A}^{1.13} \mathrm{SL}^{2.19} & 60 \\
\mathrm{Q}_{100} & =0.252 \mathrm{~A}^{1.11} \mathrm{SL}^{2.19} & 69
\end{array}
$$

\section{Region 5}

(Sites with contributing drainage areas less than 32 square miles)

$$
\begin{aligned}
\mathrm{Q}_{2} & =159 \mathrm{~A}^{0.680} \\
\mathrm{Q}_{5} & =396 \mathrm{~A}^{0.773} \\
\mathrm{Q}_{10} & =624 \mathrm{~A}^{0.820} \\
\mathrm{Q}_{25} & =997 \mathrm{~A}^{0.866} \\
\mathrm{Q}_{50} & =278 \mathrm{~A}^{0.973} \mathrm{SL}^{0.360} \\
\mathrm{Q}_{100} & =295 \mathrm{~A}^{1.01} \mathrm{SL}^{0.405}
\end{aligned}
$$

\section{$\underline{\text { Region } 5}$}

(Sites with contributing drainage areas greater than 32 square miles)

$$
\begin{array}{rlrl}
\mathrm{Q}_{2} & =377 \mathrm{~A}^{0.498} & & 43 \\
\mathrm{Q}_{5} & =1,270 \mathrm{~A}^{0.534} \mathrm{SH}^{-0.145} & & 28 \\
\mathrm{Q}_{10} & =2,310 \mathrm{~A}^{0.552} \mathrm{SH}^{-0.221} & 28 \\
\mathrm{Q}_{25} & =4,330 \mathrm{~A}^{0.571} \mathrm{SH}^{-0.307} & 31 \\
\mathrm{Q}_{50} & =6,450 \mathrm{~A}^{0.583} \mathrm{SH}^{-0.366} & 36 \\
\mathrm{Q}_{100} & =9,180 \mathrm{~A}^{0.594} \mathrm{SH}^{-0.420} & 41
\end{array}
$$

\section{$\underline{\text { Region } 6}$}

$$
\begin{array}{rlrl}
\mathrm{Q}_{2} & =66.2 \mathrm{~A}^{0.630} \mathrm{SH}^{-0.423} & & 96 \\
\mathrm{Q}_{5} & =931 \mathrm{~A}^{0.424} \mathrm{SL}^{-0.410} & 60 \\
\mathrm{Q}_{10} & =1,720 \mathrm{~A}^{0.410} \mathrm{SL}^{-0.419} & & 49 \\
\mathrm{Q}_{25} & =3,290 \mathrm{~A}^{0.398} \mathrm{SL}^{-0.428} & & 51 \\
\mathrm{Q}_{50} & =4,970 \mathrm{~A}^{0.391} \mathrm{SL}^{-0.434} & 63 \\
\mathrm{Q}_{100} & =1,780 \mathrm{~A}^{0.440} & & 75
\end{array}
$$

\section{Region 7}

(Sites with contributing drainage areas less than 32 square miles)

$$
\begin{array}{rlrl}
\mathrm{Q}_{2} & =832 \mathrm{~A}^{0.568} \mathrm{SL}^{-0.285} & 57 \\
\mathrm{Q}_{5} & =584 \mathrm{~A}^{0.610} & & 46 \\
\mathrm{Q}_{10} & =831 \mathrm{~A}^{0.592} & & 43 \\
\mathrm{Q}_{25} & =1,196 \mathrm{~A}^{0.576} & & 46 \\
\mathrm{Q}_{50} & =1,505 \mathrm{~A}^{0.566} & 51 \\
\mathrm{Q}_{100} & =1,842 \mathrm{~A}^{0.558} & 57
\end{array}
$$


Table 1. Regression equations for estimating peak-streamflow frequency for hydrologic regions of Texas (from Asquith and Slade, 1997) - Continued

\begin{tabular}{|c|c|c|c|}
\hline Regression equation & $\begin{array}{l}\text { Weighted } \\
\text { standard } \\
\text { error of } \\
\text { estimate, } \\
\text { in percent }\end{array}$ & Regression equation & $\begin{array}{c}\text { Weighted } \\
\text { standard } \\
\text { error or } \\
\text { estimate, } \\
\text { in percent }\end{array}$ \\
\hline \multicolumn{2}{|l|}{$\underline{\text { Region } 7}$} & \multicolumn{2}{|l|}{$\underline{\text { Region } 10}$} \\
\hline \multicolumn{2}{|c|}{$\begin{array}{l}\text { (Sites with contributing drainage areas greater than } \\
32 \text { square miles) }\end{array}$} & \multicolumn{2}{|c|}{$\begin{array}{l}\text { (Sites with contributing drainage areas less than } 32 \\
\text { square miles) }\end{array}$} \\
\hline $\mathrm{Q}_{2}=129 \mathrm{~A}^{0.578} \mathrm{SL}^{0.364}$ & 66 & $\mathrm{Q}_{2}=54.9 \mathrm{~A}^{0.788} \mathrm{SL}^{0.279}$ & 54 \\
\hline $\mathrm{Q}_{5}=133 \mathrm{~A}^{0.605} \mathrm{SL}^{0.578}$ & 54 & $\mathrm{Q}_{5}=80.7 \mathrm{~A}^{0.835} \mathrm{SL}^{0.330}$ & 40 \\
\hline $\mathrm{Q}_{10}=178 \mathrm{~A}^{0.644} \mathrm{SL}^{0.699} \mathrm{SH}^{-0.239}$ & 51 & $\mathrm{Q}_{10}=98.2 \mathrm{~A}^{0.860} \mathrm{SL}^{0.359}$ & 38 \\
\hline $\mathrm{Q}_{25}=219 \mathrm{~A}^{0.651} \mathrm{SL}^{0.776} \mathrm{SH}^{-0.267}$ & 51 & $\mathrm{Q}_{25}=122 \mathrm{~A}^{0.887} \mathrm{SL}^{0.390}$ & 38 \\
\hline $\mathrm{Q}_{50}=261 \mathrm{~A}^{0.653} \mathrm{SL}^{0.817} \mathrm{SH}^{-0.291}$ & 54 & $\mathrm{Q}_{50}=141 \quad \mathrm{~A}^{0.904} \mathrm{SL}^{0.408}$ & 41 \\
\hline $\mathrm{Q}_{100}=313 \mathrm{~A}^{0.654} \mathrm{SL}^{0.849} \mathrm{SH}^{-0.316}$ & 60 & $\mathrm{Q}_{100}=159 \quad \mathrm{~A}^{0.920} \mathrm{SL}^{0.426}$ & 43 \\
\hline \multicolumn{2}{|l|}{$\underline{\text { Region } 8}$} & \multicolumn{2}{|l|}{$\underline{\text { Region } 10}$} \\
\hline $30.7 \mathrm{~A}^{0.672} \mathrm{SL}^{0.652}$ & 51 & \multicolumn{2}{|c|}{$\begin{array}{l}\text { (Sites with contributing drainage areas greater than } \\
32 \text { square miles) }\end{array}$} \\
\hline $\mathrm{Q}_{5}=87.6 \mathrm{~A}^{0.668} \mathrm{SL}^{0.520}$ & 43 & $\mathrm{Q}_{2}=16.9 \mathrm{~A}^{0.798} \mathrm{SL}^{0.777}$ & 63 \\
\hline $\mathrm{Q}_{10}=134 \mathrm{~A}^{0.675} \mathrm{SL}^{0.475}$ & 43 & $\mathrm{Q}_{5}=33.0 \mathrm{~A}^{0.790} \mathrm{SL}^{0.795}$ & 51 \\
\hline $\mathrm{Q}_{25}=191 \mathrm{~A}^{0.690} \mathrm{SL}^{0.444}$ & 46 & $\mathrm{Q}_{10}=51.3 \mathrm{~A}^{0.775} \mathrm{SL}^{0.785}$ & 43 \\
\hline $\mathrm{Q}_{50}=229 \mathrm{~A}^{0.703} \mathrm{SL}^{0.443}$ & 49 & $\mathrm{Q}_{25}=87.9 \mathrm{~A}^{0.752} \mathrm{SL}^{0.760}$ & 38 \\
\hline \multirow[t]{2}{*}{$\mathrm{Q}_{100}=261 \mathrm{~A}^{0.718} \mathrm{SL}^{0.429}$} & \multirow[t]{2}{*}{51} & $\mathrm{Q}_{50}=129 \mathrm{~A}^{0.733} \mathrm{SL}^{0.735}$ & 36 \\
\hline & & $\mathrm{Q}_{100}=187 \mathrm{~A}^{0.713} \mathrm{SL}^{0.708}$ & 36 \\
\hline $\mathrm{Q}_{2}=278 \mathrm{~A}^{0.526}$ & 54 & \multicolumn{2}{|l|}{$\underline{\text { Region } 11}$} \\
\hline $\mathrm{Q}_{5}=329 \mathrm{~A}^{0.645} \mathrm{SL}^{0.220} \mathrm{SH}^{-0.246}$ & 49 & $\mathrm{Q}_{2}=159 \mathrm{~A}^{0.669} \mathrm{SH}^{-0.262}$ & 43 \\
\hline $\mathrm{Q}_{10}=350 \mathrm{~A}^{0.691} \mathrm{SL}^{0.343} \mathrm{SH}^{-0.321}$ & 46 & $\mathrm{Q}_{5}=191 \mathrm{~A}^{0.696} \mathrm{SL}^{0.130} \mathrm{SH}^{-0.186}$ & 43 \\
\hline $\mathrm{Q}_{25}=382 \mathrm{~A}^{0.743} \mathrm{SL}^{0.466} \mathrm{SH}^{-0.413}$ & 49 & $\mathrm{Q}_{10}=199 \mathrm{~A}^{0.718} \mathrm{SL}^{0.221} \mathrm{SH}^{-0.151}$ & 49 \\
\hline $\mathrm{Q}_{50}=409 \mathrm{~A}^{0.778} \mathrm{SL}^{0.541} \mathrm{SH}^{-0.477}$ & 49 & $\mathrm{Q}_{25}=201 \mathrm{~A}^{0.713} \mathrm{SL}^{0.313}$ & 54 \\
\hline \multirow{2}{*}{$\mathrm{Q}_{100}=438 \mathrm{~A}^{0.811} \mathrm{SL}^{0.607} \mathrm{SH}^{-0.539}$} & \multirow[t]{2}{*}{54} & $\mathrm{Q}_{50}=207 \mathrm{~A}^{0.735} \mathrm{SL}^{0.380}$ & 60 \\
\hline & & $\mathrm{Q}_{100}=213 \mathrm{~A}^{0.755} \mathrm{SL}^{0.442}$ & 66 \\
\hline
\end{tabular}

Table 2. Range of explanatory variables for which regression equations are applicable (from Asquith and Slade, 1997)

$\left[\mathrm{mi}^{2}\right.$, square miles; A, contributing drainage area $\left(\mathrm{mi}^{2}\right) ; \mathrm{SH}$, basin shape factor - ratio of length of longest mapped channel (stream length) squared to contributing drainage area (dimensionless); SL

stream slope - ratio of change in elevation of (1)

longest mapped channel from site to headwaters to (2) length of longest mapped channel (feet per mile)]

\section{Hydrologic}

region

A

SH

SL

Region $1 \quad 1.15-2,956 \quad 0.11-80.9 \quad 2.49-132$

Region $2 \quad 0.32-4,305 \quad 0.51-14.8 \quad 9.67-130$

Region 3 (Sites with A less than $32 \mathrm{mi}^{2}$ ) 0.10-97.0 0.16-9.32 10.7-105

(Sites with A greater than $32 \mathrm{mi}^{2}$ ) $11.8-14,635 \quad 1.71-75.0 \quad 4.81-36.3$

Region 4 (Sites with A less than $32 \mathrm{mi}^{2}$ ) $0.19-81.1 \quad 0.05-6.52 \quad 13.5-226$

(Sites with A greater than $32 \mathrm{mi}^{2}$ ) $12.0-19,819 \quad 0.49-19.7 \quad 3.52-36.1$

Region 5 (Sites with A less than $32 \mathrm{mi}^{2}$ ) 0.18-22.3 $\quad 0.50-84.9 \quad 20.9-224$

(Sites with A greater than $32 \mathrm{mi}^{2}$ ) $45.0-1,861 \quad 3.14-20.8 \quad 9.86-48.8$

Region 6 (Sites with A less than $32 \mathrm{mi}^{2}$ ) 0.36-15,428 0.011-10.9 6.88-98.9

Region 7 (Sites with A less than $32 \mathrm{mi}^{2}$ ) $0.20-78.7 \quad 0.037-36.6 \quad 7.25-116$

(Sites with A greater than $32 \mathrm{mi}^{2}$ ) $13.0-2,615 \quad 1.66-36.6 \quad 3.85-31.9$

Region $8 \quad 0.75-7,065 \quad 1.94-24.8 \quad 3.83-39.5$

Region $9 \quad 0.24-5,198 \quad 0.091-30.1 \quad 2.77-70.0$

Region 10 (Sites with A less than $32 \mathrm{mi}^{2}$ ) 0.21-100 0.008-1.05 2.00-138

(Sites with A greater than $32 \mathrm{mi}^{2}$ ) $23.4-6,507 \quad 1.77-16.9 \quad 1.48-24.5$ Region $11 \quad 0.13-3,636 \quad 0.082-18.8 \quad 0.38-169$ 